\title{
WRESTLING WITH THE GOD WHO WEEPS: FYODOR DOSTOEVSKY AND THE PHILOSOPHY OF JOSEPH SMITH
}

\author{
Spencer B. JUDD \\ B.A. Philosophy, New York University \\ B.S. Finance, Stern School of Business, New York University, \\ United States of America \\ Email: spencer.judd@stern.nyu.edu
}

\begin{abstract}
"Strange! that you should not have suspected years ago-centuries, ages, eons, ago! - for you have existed, companionless, through all the eternities. Strange, indeed, that you should not have suspected that your universe and its contents were only dreams, visions, fiction! Strange, because they are so frankly and hysterically insanelike all dreams: a God who could make good children as easily as bad, yet preferred to make bad ones; who could have made every one of them happy, yet never made a single happy one; who made them prize their bitter life, yet stingily cut it short; who gave his angels eternal happiness unearned, yet required his other children to earn it; who gave his angels painless lives, yet cursed his other children with biting miseries and maladies of mind and body; who mouths justice and invented hell-mouths mercy and invented hell-mouths Golden Rules, and forgiveness multiplied by seventy times seven, and invented hell; who mouths morals to other people and has none himself; who frowns upon crimes, yet commits them all; who created man without invitation, then tries to shuffle the responsibility for man's acts upon man, instead of honorably placing it where it belongs, upon himself; and finally, with altogether divine obtuseness, invites this poor, abused slave to worship him!"
\end{abstract}

\section{ABSTRACT}

-Mark Twain, The Mysterious Stranger

This paper contains three acts, so to speak, each part analyzing approaches to the philosophical Problem of Evil within the 19th century. This is done by juxtaposing some of the strongest arguments over the Problem of Evil. Before going into the arguments themselves, I survey the movements of the 19th century and specifically examine a 19th century piece of art by Alexander Leloir, symbolizing man's struggle with God, and use his image as my model for channeling the following two arguments. I then examine a piece of literature from the 19th century, The Brothers Karamazov, by Fyodor Dostoevsky, focusing specifically on his character Ivan Karamazov's critique of God in regard to the suffering of children and the innocent. Ivan gives one of the best articulations of the atheist critique of God's amorality and allowance of evil. Following that, I examine the religious philosophy of a 19th century figure, Joseph Smith, whose contributions I attempt to show provide a valid theodicy for acquitting God from the Problem of Evil, due to the conception of God, Mankind, and a christogenic cosmos that Smith introduces. While an entire exhaustive treatment on the problem of evil would require a lot more space then this paper can presently afford, this is a synthesized account of the compelling arguments of each side. This paper isn't to invalidate or delegitimize past, present, and future suffering. The rationalization of evil, even if it be with profound meaning, isn't sufficient on its own to eradicate the consequences of evil, nor to fully comfort its victims. This exercise might untangle webs of logical confusion and cognitive dissonance, but it does not in of itself end the poverty in third world countries, horrific wars and acts of terror, bullying, prejudice, or homelessness, to name a few examples. I recognize that explanations for the horrors of history can sound trite and 
trivial, almost at times an insult. Even if Smith's position proves logically coherent, I recognize this paper has only solved the logical problem of evil rather than the actual problem of evil in our world. It simply seeks to understand the problem and examine ways that make it meaningful, rather than eradicating it. The problem cannot be solved through a logical proof on a chalkboard or in an argument through a paper. Nevertheless, all action is derived from how we think and what we desire, which in turn can be impacted by words and ideas, and for that I believe this paper holds relevant value. Hopefully these chambers of reflection serve as a catalyst to action, to contribute a verse into the lessening of others' suffering.

Keywords: Wrestling; God who Weeps; Fyodor Dostoevsky; Philosophy of Joseph Smith;

\section{INTRODUCTION}

Theodicy is bred upon a lamentable tendency we have as humans to use more time theorizing the reasons behind suffering than actually alleviating it. Be that as it may, the paradoxical proposal of the dual existence of both a loving God and genuine evil is one that is a psychological burden of cognitive dissonance for billions, a burden likewise in need of alleviation and thus explanation. In addition to evil's attack to our happiness, there is no greater threat to belief in a personal, loving God than in the Problem of Evil. Philosopher Truman Madsen has accurately articulated the existential problem that we are faced with in his book Eternal Man:

Let us walk into a hospital: Here. This newborn infant with the lovely face. She could not have worthier parents. But she was born in total paralysis and is blind. The doctors do not know if she will survive. And if she does . . . This bed is empty. Its occupant, a quivering psychotic with a wild stare, is upstairs undergoing shock treatment. He collapsed when his wife and two children were maimed in a fire, one beyond recognition. Over here is a surgeon who had a rare brain disease and asked his closest friend to operate. The operation failed; and he has been, for nearly three years, a human vegetable. His friend has since committed suicide. Somewhere tonight the families of these souls are crying themselves to sleep. Now, if your arm will hold out, write as many zeros after a " 1 " as will portray similar reenactments of these scenes that are, or have been, or may be, on this planet. And that will be one thread in the tapestry of human misery (Madsen 39).

The diversity and intensity of suffering on this planet is staggering: genocide, homelessness, war, mental illness or insanity, natural disasters, divided families, selves divided, injustice, torture, disease, inequality, poverty, loneliness...these are but a few on the endless list. The logical dilemma of suffering was concisely summarized by the philosopher Epicurus when he asked, "Is God willing to prevent evil, but is not able? Then he is not omnipotent. Is he able, but not willing? Then he is malevolent. Is he both willing and able? Then whence cometh evil? Is he neither willing nor able? Then why call him God?" (Lactantius 494). But our dilemma is more than just an academic toy but, as Madsen points out, is in fact a real-world problem we all grapple with. Any mention of Auschwitz, Sandy Hook, or 9/11 brings immediate reverence as we ponder over this most devastating problem that has probed more adults to ask 'Why?' than their two-year-old kids. Why, indeed? Some examine all this and conclude that there is no inherent purpose behind it all, behind any of it. Mankind is simply coercively thrust into a short existence of meaninglessness and chaos in godless geometric space, where evil reigns with blood and horror, all before disappearing into oblivion with the vast death of the solar system into an abyss of nothingness. Solving the problem of evil (logical or existential) is a most relevant quest then, as it is inextricably tied to the terrifying questions surrounding the ultimate signification of, what is for some, the 
burden of existence. Any "solution", though, to be sufficient, should strive for Rabbi Irving Greenberg's high standard for theodicy made to those attempting rationalizations for the horrors at Auschwitz: "No statement, theological or otherwise, should be made that would not be credible in the presence of burning children"(Irving 253). Diverse approaches have been taken over the last two millennia, from Plato to Augustine, to Buddha and Leibniz, but especially through monumental explorations in human thought in the $19^{\text {th }}$ century, such as from Fyodor Dostoevsky and Joseph Smith. It was that particular century that put God on trial yet again, allowing the emergence of some of His most fierce prosecutors as well as a new, revolutionary theodicy.

\section{OF RELIGIONS AND REVOLUTIONS}

Terryl Givens, a professor of intellectual history, has written in his article, "Lightning out of Heaven", of the influential shifts in the intellectual atmosphere of the 18th and 19th centuries that have largely impacted our modern discussions of God. The combination of the Age of Enlightenment with the Romantic movement brought about, "an irrepressible optimism about human potential, a growing embrace of human dignity and freedom as the birthright of every man, and, in many cases, doubts that such values and aspirations could be compatible with...oppressive, inflexible orthodoxies, rigid hierarchies, and stultifying systems of religion that almost universally emphasized human depravity, inherent guilt, and arbitrary omnipotence" (Givens 3). The general mood evoked from religion at that time was of despair over the tragic nature of the human condition. In response to being ruled by monarchies, masters, and machines, these centuries were marked by myriad revolts. What resulted was not just a time of political, social, or industrial revolution, but also theological revolution. This new environment allowed previously unconventional ideas to gain traction and spread quickly. Reactions ranged from radical new views of God to atheism.

On January 21st, 1793, King Louis of France was beheaded. Existentialist philosopher Albert Camus referred to that execution as "the crux of our contemporary history." Why? Since Louis's appointment as king was thought to be by divine right rather than a democratic system, rebellion against him was also seen as rebellion against God (Givens). This act of exiling God marked the beginning of the rapid decline of God's former unquestioned status in the West. It was this revolt against Deity that would inspire others to similarly stand up against holes in the holy. This motivation derived in part from dissatisfaction with dominant theology's limitedness and constant resort to mystery to account for the behavior and purposes of God, not to mention the repression of alternative, but unorthodox, rationales. In his article, "No Small and Cramped Eternities", Givens describes some of the underlying gnawing anxieties as such:

The questions that Christian theology has by and large resisted the urge to adjudicate are legion. What of the time before Creation? What was God doing then? What of God's other dominions? Another mystery it falls not to theology to explain. Why is there man at all? For Milton, the boldest exponent of theodicy before Parley Pratt, it was to deprive Satan of bragging rights in having suborned a third of heaven's angels. The scriptures, however, are silent. What of human destiny in the worlds beyond? What is man being saved for? Dante thought a state of eternal, rapturous contemplation, and few have proffered more specifics than that. Post-redemption theology is an oxymoron. So traditional theology, in other words, confines itself to defining the terms and conditions of a very limited concept of salvation, of a soul of unknown beginnings, from an evil of unknown origin, to prepare for a future of unknown nature, all in accordance with the inscrutable will of a God who is beyond human comprehending (Givens). 
Givens notes that the theologian Augustine, when famously asked what God was doing before creation, was tempted to respond, "creating hell for people who ask such impudent questions" (2). While Augustine was an intellectual by all accounts, this avoidant reply perfectly characterizes the type of anti-intellectual inquisition to inquiry that later church leaders would exercise, including to issues of suffering and inequality, instead appealing to mystery or incomprehensibility. This tension that arose from strict "orthodoxy", would unsuspectingly fuel the rationally repressed and the subsequent religious revolutions, allowing the emergence of new religious thought and prompting an avalanche of inspiration for art and literature.

\section{JACOB'S WRESTLE}

One 19th century example of art's theodic exploration of mankind's struggle with God is Alexander Leloir's painting, Jacob Wrestling the Angel, produced in 1865. This painting depicts the biblical story of Jacob, who while in isolation and concern for his family's safety, confronts a celestial being (Genesis 32). Many Christian and Jewish scholars' interpretations actually have Jacob wrestling God Himself rather than an angel (Berger, Kolitz).

Jacob's plight is quite symbolic of the intellectual entanglement that occurs in the search of theodicy. Instead of a simple miracle, easily received by a simple prayer, Jacob's reward is received after a prolonged wrestle with God. His hip is dislocated and he wrestles through the dark of night. Upon the break of dawn, after passing the trial, he is given the blessing of a new name, Israel, which means "He who struggles with God".

Hugh Nibley notices that "the word conventionally translated as 'wrestled' can just as well mean "embrace" (Nibley 243). Regardless of the actual intent of the word, these little insights offer two differing reactions, both to the painting and the problem of evil. Leloir's painting majestically depicted a biblical symbol of suffering and the cognitive dissonance we have at a Being who supposedly has the power and the motive to deliver us but doesn't. With Nibley's alternative insight, the story is instead a symbol of mankind's life long journey and struggle with God that begins as a wrestle and transforms into embrace.

\section{IVAN KARAMAZOV}

One of the greatest books in literature that likewise touches on the paradox of suffering in the world is The Brothers Karamazov by Fyodor Dostoevsky. Dostoevsky was praised by countless intellectuals throughout history such as Camus, Einstein, Sartre, and Nietzsche for his psychological and philosophical insights. Freud considered him, next to Shakespeare, as the greatest writer of all time. Published in 1880, this book is the tale of three brothers, Alyosha (a monk), Ivan (a hard skeptic), and Dmitri (who remains morally divided throughout the story). The story is filled with each brother's journey showing their strengths and struggles, all while discussing human nature, God, morality, and human suffering. In an epic dialogue between Ivan and Alyosha, Ivan goes on a sophisticated diatribe with detailed stories of the torture of children and a cost/benefit analysis of salvation and allegiance to God. Ivan, representing the unspoken doubters of the generation, was bold enough to confront and reject the God of his contemporaries.

Ivan isn't simply torn over the question of the logical possibility of the existence of an omnipotent God with a universe filled with evil, but rather is concerned why anyone would seriously believe this being is one worthy of our love. What really sears his soul is the "notion that an all-powerful, perfect, and self-sufficient deity, that required no world and no 
other being beside Himself, would create a world full of sinners whose fate would be temporal suffering here and eternal suffering hereafter (McLachlan) ${ }^{1}$. His basis for doubt in God, not as he notes in His existence, but in His goodness, is based in this challenge:

Imagine that you are creating a fabric of human destiny with the object of making men happy in the end, giving them peace and rest at last, but that it was essential and inevitable to torture to death only one tiny creature - that baby beating its breast with its fist, for instance - and to found that edifice on its unavenged tears, would you consent to be the architect on those conditions? (Dostoevsky 308).

The ethical dilemma Ivan sees God facing, is whether His great plan would be worth the necessity of allowing the torture of at least one unfortunate child in the scope of mankind's history (although the dilemma at hand really extends to millions of other children through history, not just one) for the happiness and eventual salvation of all others. It's hard enough to answer this challenge when we are posed the question, but Ivan points out that the absurdity its grossly more unethical if you are God. If you are almighty, omnipotent God, (with whom nothing is supposedly impossible, and who is responsible for creating all the rules of how things work in the universe, including how to be saved) why even consider a world on such conditions in the first place, when you could have done otherwise? When you could have made a means of salvation without such extreme needless suffering? Why should the higher harmony of heaven be built on the suffering and innocent suffering of others? "Surely [even] I haven't suffered simply that I, my crimes and my sufferings, may manure the soil of the future harmony for somebody else" (307). Why create a universe that necessitates that our happiness in Heaven only comes at the expense of others inevitably suffering in Hell, (on earth and in the afterlife)?

Ivan questions whether the prices of mortality are worth the "diabolical good" and harmony of everlasting heaven. To highlight the disturbing paradox of the classical Christian plan of salvation, he shares a story of the torture of a five-year-old from abusive parents:

This poor child of five was subjected to every possible torture by those cultivated parents. They beat her, thrashed her, kicked her for no reason till her body was one bruise. Then, they went to greater refinements of cruelty - shut her up all night in the cold and frost in a privy, and because she didn't ask to be taken up at night (as though a child of five sleeping its angelic, sound sleep could be trained to wake and ask), they smeared her face and filled her mouth with excrement, and it was her mother, her mother did this. And that mother could sleep, hearing the poor child's groans! The child screams. But at last the child cannot scream, it gasps, 'Daddy daddy!' Can you understand why a little creature, who can't even understand what's done to her, should beat her little aching heart with her tiny fist in the dark and the cold, and weep her meek unresentful tears to dear, kind God to protect her? Do you understand that, friend and brother, you pious and humble novice? Do you understand why this infamy must be and is permitted? Without it, I am told, man could not have existed on earth, for he could not have known good and evil. Why should he know that diabolical good and evil when it costs so much? Why, the whole world of knowledge is not worth that child's prayer to dear, kind God (Dostoevsky 306)!

Can you imagine yourself, much less God, hearing this tender, desperate prayer for rescue and deliverance from torture from this innocent angel and responding with silence, inaction, or cold indifference?

\footnotetext{
${ }^{1}$ Due to the properties of self-aseity and absolute perfection ascribed to God (as many theologians strictly hold to), He would lack nothing and would have no need to change. Being compelled to change, for whatever reason, would imply that He lacks something, and would need some sort of further development which would contradict the principle of absolute perfection.
} 
Ivan does not entirely sympathize with the suffering of adults as he can conceive of potential reasons that justifies their suffering, "Men are themselves to blame, I suppose; they were given paradise, they wanted freedom, and stole fire from heaven, though they knew they would become unhappy, so there is no need to pity them" (305). Seeing adults as inherently sinful and evil, he sees them as deserving of such suffering to pay for their crimes.

But what of suffering of those who committed no crime? As Ivan elaborates, "I want to see with my own eyes the hind lie down with the lion and the victim rise up and embrace his murderer. I want to be there when everyone suddenly understands what it has all been for. All the religions of the world are built on this longing, and I am a believer. But then there are the children, and what am I to do about them? If it is really true that they must share responsibility for all their fathers' crimes, such a truth is not of this world and is beyond my comprehension" (306). Ivan then proceeds with an additional story of a boy who accidently hurts a powerful general's favorite dog. For his offense, the child is stripped naked, tortured, and torn to pieces by a pack of dogs, with his mother forced to watch. What of justice and harmony here? "Some jester will say, perhaps, that the child would have grown up and have sinned, but you see he didn't grow up, he was torn to pieces by the dogs, at eight years old. Why should they, too, furnish material to enrich the soil for the harmony of the future?", asks Ivan (306). His critique of Christianity's cosmic salvation climaxes in ultimate confusion over the atonement of innocent suffering (rather than $\sin$ ) and with open rebellion against God:

I understand, of course, what an upheaval of the universe it will be when the mother embraces the fiend who threw her child to the dogs, and all three cry aloud with tears, 'Thou art just, O Lord!' then, of course, the crown of knowledge will be reached and all will be made clear. But what pulls me up here is that I can't accept that harmony. I renounce the higher harmony altogether. It's not worth the tears of that one tortured child who beat itself on the breast with its little fist and prayed in its stinking outhouse, with its unexpiated tears to 'dear, kind God'! It's not worth it, because those tears are unatoned for. They must be atoned for, or there can be no harmony. But how? How are you going to atone for them? Is it possible? By their being avenged? But what do I care for avenging them? What do I care for a hell for oppressors? What good can hell do, since those children have already been tortured? And what becomes of harmony, if there is hell? I want to forgive. I want to embrace. I don't want more suffering. And if the sufferings of children go to swell the sum of sufferings which was necessary to pay for truth, then I protest that the truth is not worth such a price. I don't want the mother to embrace the oppressor who threw her son to the dogs! She dare not forgive him! Let her forgive him for herself, if she will, let her forgive the torturer for the immeasurable suffering of her mother's heart. But the sufferings of her tortured child she has no right to forgive; she dare not forgive the torturer, even if the child were to forgive him! And if that is so, if they dare not forgive, what becomes of harmony? Is there in the whole world a being who would have the right to forgive and could forgive? I don't want harmony. From love for humanity I don't want it. I would rather be left with the unavenged suffering. I would rather remain with my unavenged suffering and unsatisfied indignation, even if I were wrong. Besides, too high a price is asked for harmony.

For the absolute contradiction of God's supposed absolute goodness with an allowance of such atrocious suffering to undeserving innocent children, Ivan tells Alyosha, "In all humility, I cannot understand why the world is arranged as it is. It's not God that I don't accept, Alyosha, only I most respectfully return him the ticket" (308). Torn over the absurdity of the unjust, lop-sided reality God created, he returns his ticket to heaven rather than adore and bow to an unjust God. Ivan concludes that "the world stands on absurdities", 
that the devil is an anthropomorphic projection created in the image of humanity, and that if God does exist, He is as equally void of goodness (304). ${ }^{2}$

Interestingly, despite the seriousness of his argument through Ivan, Dostoevsky was a believer in God till his death. How he reconciled a belief with these self-projected doubts are unknown, but this Dostoevskian theme of an individual divided in schizophrenic tension was a common one that he projected onto many of his characters and stories. Through the character of Ivan, Dostoevsky did not shy from honestly confronting the problematic inconsistencies of some of his own beliefs, thus revealing some of the core problems with which he was wrestling with God. Ivan's argument is not just challenging, it is one that Dostoevsky and his characters could never refute. Dostoevsky readily recognized in letters to editors the insufficiency of Alyosha's attempts to morally and aesthetically (not just rationally) justify belief in God with the reality of extreme evils, a position that Ivan so terribly slaughtered. Ivan's entire reaction to God, of a morally and rationally justified rebel against ultimate authority, foreshadowed the critique, anger, and incredulity that many would have towards God in the coming century even to our present day to conclude, in harmony with atheists, existentialists, and Nietzsche, that God is dead.

\section{JOSEPH SMITH}

A contemporary thinker of the 19th century who indirectly proposed new ideas on the problem of evil was Joseph $\mathrm{Smith}^{3}$, a religious iconoclast termed by famous literary critic Harold Bloom as "a religious genius" for his audacious and provocative thinking (Bloom 95). Smith, with Ivan, likewise rejected the dominant depiction of God in their time, but instead of returning the ticket or resorting to atheism, Smith introduced new approaches to many of the paradoxes that had surrounded God for centuries, including the philosophical problem of evil. While there have been various approaches to the troubles of theodicy ${ }^{4}$, Smith swiftly cut several Gordian knots by introducing revolutionary views of God, mankind, and their relationship, through multiple books and discourses he claimed to be inspired revelations from God rather than simply theological speculations. ${ }^{5}$ These understudied monumental works include the Book of Mormon, the Doctrine and Covenants, the Pearl of Great Price, and the King Follet Discourse, all of which Smith delivered before being murdered at 38.

One of the most potent factors hindering a solution to the problem of evil had been the centuries-long rigid orthodoxy of classical Christianity on various points of God's, man's, and the universe's nature and motives. Much of historical Christian conception of God can be derived, not to the Bible, but to $4^{\text {th }}$ century man-made creeds, unbiblical in content, extrabiblical in derivation, that attempted to reinvent the God of the Bible to fit their modern-day

\footnotetext{
${ }^{2}$ For Ivan's entire argument well worth reading see Works Cited-Brothers Karamazov Dialogue.

${ }^{3}$ For the most updated and exhaustive biography of Smith: Rough Stone Rolling by Columbia's Richard Bushman. For an additional biography, see Joseph Smith the Prophet by Truman Madsen.

${ }^{4}$ Among other views, Augustine held that evil was simply the absence of good. This view is held by Roman Catholicism. Buddhism and Christian Science see evil as illusory. Leibniz and Spinoza saw evil as perspectival, that from a complete understanding of all events and their purposes, what we currently deem evil will not be deemed evil from that complete perspective. Smith's views can be seen partially as perspectival, but mainly as instrumentalist. Smith rejects evil as illusory and sees it as genuinely real.

${ }^{5}$ While my paper is titled the philosophy of Joseph Smith, it's important to know that while his thoughts have made several valuable contributions to philosophical discussion, he did not claim to be technically philosophizing, nor did he have any competent academic background for the work he produced. His works usually came through sporadic breakthroughs of insight, not drafted and edited papers after months of research and reflection, nor as a thoroughly systematic finished product.
} 
philosophies. This official depiction of the Christian God came about not by revelation from God himself, but by majority vote by the bishops of the $4^{\text {th }}$ century ${ }^{6}$. What arose from the creeds of various councils and church theologians is what has been called the God of the Philosophers, a God who was platonized by Augustine and aristotlized by Thomas Aquinas ${ }^{7}$. Philosopher William James put it best about this absolutization of God: "Odd evolution from the God of David's psalms!"(James 410) ${ }^{8}$. The problematic Hellenizing of original Christianity, the unfortunate marriage of Jewish religion with Greek metaphysics, established new assumptions about God in absolutistic terms, such as absolute power, absolute goodness, absolute foreknowledge, and absolute creation, or creation from nothing. Competing views of God eventually were officially ruled out, exiled as split-offs, and the new Greek conception of the Christian God became the standard for centuries, largely unquestioned and unchallenged by kings, theologians, or peasants. It wasn't until the $19^{\text {th }}$ century that Smith, at only 14 years old, pointed out, "The emperor has no clothes", or in other words, "The emperor is drenched in Greek clothes!" (Madsen).

\section{Of God}

Smith's theodic solutions came in part by stripping away premises and assumptions that had led to centuries of philosophical entanglement, thus getting out of many classical problems by never having to go into them. This accomplishment came by viewing God's capacities in terms of maximal potentiality rather than the neo-platonic concept of absolutism. On top of many changes, one of its most important was abandoning the idea of creation ex nihilo, or creation of something out of nothing. Apart from its inherent illogicality, it also has problematic implications relating to the problem of evil. Philosophers have long noticed that if God created everything, then ultimately, $\mathrm{He}$ was responsible for all the evil in the world, having created evil or a world and beings with the capacity to do so. Additionally, having absolute foreknowledge means that He would have knowingly created a chaotic cosmos for which most of humanity would experience immense suffering, not to mention consigning the majority of humans (billions upon billions) by His criteria for salvation, to eternal hell fire. Smith proposed a new idea of creation, salvation, and the nature of the universe. Instead of creation ex nihilo, creation was done by organizing and refining raw self-existent eternal matter, fashioning order into the chaos of an eternal cosmos. This view saw creation as comparable to building a ship from simpler materials, rather than waving a magic wand and forcing an object into existence from nothingness into being. Matter, time, and law, then, being eternal, are all uncreated, uncreatable, and indestructible. They have no beginning, they just are. This aligns with claims of modern physicist Peter Lynds that the universe is ultimately without beginning or end. In an attempt to address the Primordial Existential Question, "Why is there something rather than nothing?", as well as Kant's paradox, Lynds argues for "a universe in which time is cyclic, without beginning or

\footnotetext{
${ }^{6}$ The Nicene Creed was "made formal and given weight by majority vote and supported after much struggle by later assemblies, notably at Chalcedon (AD 451) -likewise by majority vote. Such was the determining process. Thus agreement was arrived at, and became dogma widely accepted down to our day" (MacMullen, 7). "Voting about God in the Early Church Councils".

${ }^{7}$ See articles by Nels F.S. Ferre, Norbert Samuelson, Robin Atfield, Karl Rahner, James Barr, John Barton, Lee McDonald, James Sanders, and James VanderKam in Works Cited. See Judah Halvie, Pascal, and Martin Buber for further references. Also, for a list of the absolutistic qualities of the classical Christian God see Works CitedProperties of the classical Christian God.

"I can hardly conceive of anything more different from the absolute, than the God, say, of David or Isaiah" (James 54, Varities).
} 
end, exists eternally, and yet, in relation to time is also finite" (Lynds 8). Philosophers Blake Ostler and David Paulsen explain the significance of these new conceptions Smith introduced:

Smith affirmed that God is related to and hence conditioned by an eternal environment that, because it is not totally his creation, is not absolutely subject to divine fiat. The importance of this fundamental departure from traditional theology can hardly be overstated. Smith taught that God is a dynamic being involved in progression and process of time who intervenes to bring order out of chaos. God did not bring into being the ultimate constituents of the cosmos nor the space-time matrix that defines it. Hence, unlike the Necessary Being of classical theology who alone could not not exist and on whom all else is dependent for existence, the God of Joseph Smith confronts realities that exist of metaphysical necessity independently of His own creative activity (Ostler and Paulsen).

Reviewing historical cases of science and religion's eroding relationship, Givens noted that, "In the aftermath of Sir Isaac Newton's momentous decipherment of the laws of the universe, the French scientist Pierre-Simon de Laplace famously told Napoleon, in his philosophical euphoria, that he no longer had need of God to make sense of creation". Secular science could henceforth exile God from His universe (Givens 3). But Smith solved this traditional rivalry between God and science by reinscribing God into the universe neither as a product nor producer of it or all of its laws, but rather as a being eternally co-existent with the totality of reality ${ }^{10}$ (McMurrin). God was revealed to be a being whose power came

\footnotetext{
9 "Based on the conjecture that rather than the second law of thermodynamics inevitably be breached as matter approaches a big crunch or a black hole singularity, the order of events should reverse, a model of the universe that resolves a number of longstanding problems and paradoxes in cosmology is presented. A universe that has no beginning (and no need for one), no ending, but yet is finite, is without singularities, precludes time travel, in which events are neither determined by initial or final conditions, and problems such as why the universe has a low entropy past, or conditions at the big bang appear to be so special, require no causal explanation, is the result" (Lynds).

10"Sagan believes that somehow with no conscious planning, no one to prevision the outcome, somehow there was a conspiracy in the random world of chance that from two atoms, some proto-plasmic combination occurred and life emerged and from that pseudopodium, a biological term for a toothless cell, more complex life emerged until now I am surrounded by remarkable persons who are alive and conscious and capable of all kinds of things, including rational thought. This view also comes to a kind of pessimism because there is no known immortality for selves, selves die and disintegrate, and it is entirely possible that in due time we will all experience that vast and total death and there will be no life and no consciousness left in the universe. When those who want to apply the teleological argument that want to say "how do you account for the incredible amount of order and harmony in the universe?", and then say it would be 1 chance over....all the zeros you can write, that this world with this kind of order and with life could have sprung up by chance. And the answers of these persons would be: "all I need is one. One over whatever because that's what we have, we have an infinity in the universe". By the same principle, if it could happen once, then even after the so-called total death of the universe, it could happen again. To say it couldn't, is to say what they don't want to say, "oh you had at least one chance of that". And its also possible isn't it, that sometime in the remote and infinite future, one person who has emerged simply by chance could gain sufficient knowledge and power over the universe to perpetuate life and thus introduce immortality into the universe? And is it not even then possible that there's one chance over infinity that one person could emerge as...God? Having all the qualities and attributes we have heretofore assigned to Him? To say, "No that could never happen" is not a very plausible position for a person who insists that by chance you came into existence" (Madsen). Such arguments that speculate on how theosis can naturally occur in an evolving universe inspire new philosophical movements, like Transhumanism, to speculate on our future godlike abilities that may be achieved through human progress, transforming human life and capacity in the process into god-like beings. David Pearce summarizes possibilities transhumanists hope to actualize across three main areas: "Superintelligence, to radically enhance intellectual abilities, Superlongevity, there is no immutable law of nature that says organic robots must grow old anymore than silicon robots. Thus this seeks to
} 
from knowledge and mastery of the self-existent laws of the universe rather than by inherently limitless ability to break, create, or contradict those laws. All events, even atypical phenomenon in nature, can be rationally and scientifically explained without having to conclude that its laws have been contradicted. For example, it is possible to lift tons of steel into the air by virtue of a jet engine and airfoil without revoking the law of gravity (Ostler). Smith implies that any activity attributed to God would also occur in similar scientific harmony. Because God is conditioned by an environment of eternal laws that are out of his power to break, God's activity isn't only incidentally compatible with logic and physics, it is necessarily compatible. For example, Brigham Young inferred from Smith's foundational teachings that if God intervenes with Earth's nature in the future he would do so by "sending forth his angels who are well instructed in chemistry, [to] separate the elements and make new combinations thereof' (Young 15:127). Due to this broader understanding of godliness, Smith saw education as a religious responsibility and academic scholarship as a form of worship (Doctrine and Covenants 93:19).

Thus, there is no magic wand in creation or miracles. God's maximal power entails that He can bring about all state of affairs that are consistent with the natures of eternal existences. Not even God has the power to make a four-sided triangle or a circular square, to force self-fulfillment onto free agents, or to organize an atom of oxygen and two atoms of hydrogen without the properties of water emerging. Miracle thus is not violation of law but a fulfillment of some higher or yet undiscovered law. From God's point of view, there are no miracles (McMurrin). Smith recorded, "The glory of God is intelligence or, in other words, light and truth" (Doctrine and Covenants 93:36). God is neither anti-scientific nor antiintellectual, but His power comes in part from, not in spite of, possessing and accumulating knowledge of truth and light of all kinds, spiritual and secular. ${ }^{11}$

By creating a naturalistic theology, this important insight merges the classically unbridgeable chasm between God and science (that still persists today), by collapsing the spiritual and the temporal into one sphere and one continuum, rather than dual natures of realities. Smith claimed that there is no such thing as immaterial substance. Everything, including spirits, angels, God, and mind are all ultimately of a material nature. Denouncing religious supernaturalism, yet embracing theology from the perspective of scientific materialism in a monistic cosmology, provided a rare metaphysical unified solution to the either/or character of physicalist/dualist metaphysics, the significance of which cannot be overstated. All this further explained the relation and extent of God's capacities with the physical universe and its laws, the relevance of which aids in understanding suffering that occurs from natural disasters. Smith's theodic success comes here by accounting for natural evils out of the impossibility of the simultaneous compossiblilty of certain desired outcomes (see Ostler's conclusion in Formal Proof), as well as God's relation to working with principles of matter as it is and fundamentally operates. This differs from the classical view in which God, with perfect power could have created the world without earthquakes, but due to some arbitrary inscrutable intent of His, didn't. Ostler and Paulsen summarize how this

understand the aging process, and assure that everyone who wants to can live an indefinite healthy lifespan, Superhappiness, to phase out substrates of suffering, and recalibrate the hedonic treadmill'(Pearce).

${ }^{11}$ In saying, "We are saved no faster than we gain knowledge", Smith offers a unique idea on the meaning of salvation by correlating, and in some sense equating, the acquisition of knowledge or understanding (spiritual, experiential, and intellectual) with one's acquisition of salvation (History of the Church, 4:588). Richard Bushman's argues that the inverse is also true: we gain knowledge no faster than we are "saved". 
new view of God's relationship with materiality and cosmos affect issues of theodicy with natural evils:

Smith maintained that matter has inherent tendencies that are eternal. In other words, God could not create matter out of nothing, he could not create matter that is not already extant in space-time, and he could not create the laws that define how matter acts once it is organized. Rather, the natural tendencies of organized matter are based on eternal principles. For example, not even God could organize an atom of oxygen and two atoms of hydrogen without the properties of water emerging from this organization. If God organizes oxygen and hydrogen into a water molecule, it has a natural tendency to freeze at 32 degrees Fahrenheit. Because these natural tendencies of organized matter exist independently of God's creative fiat, the possibility of indiscriminate natural evils is endemic to any creation God could bring about. Indeed, if God creates water, the possibility that persons may drown is also present (Ostler and Paulsen).

This view of a God limited by a body, by being inside an eternal cosmos, and by eternal laws, lead some to misunderstand the meaning of the term limited in technical descriptions of God. Ostler notes, "Calling a being, who knows every thought that you've ever had and every atom on the planet Jupiter, 'limited' and over-focusing on God's limits is missing the point [of the technical philosophical use of the word]" 12 . By revealing God as maximally powerful, instead of absolutely so, Smith's God remains supremely capable in every possible aspect that is possible. If Smith's God is limited it is only by self-limitation, by the impossible, or by co-existing eternal realities. For example, it is not possible for God to contradict logic (creating 4-sided triangles, forcing people to commit free acts), to trespass physical law, nor to perform metaphysical impossibilities (creating something out of nothing). This novel view of God, "captured the interests of talented theologians from all corners of occidental religion" (McMurrin). Many proponents (not just of the possibility but of the preference) for a limited God, have risen in the $20^{\text {th }}$ century, such as in the Practical theism of William James, in Process theism, and most recently in Open theism.

William James notes that it has been historically common across many schools of thought to conceive of God as infinite and absolute but wonders where is the warrant for jumping to this conclusion and necessitating it. "All that the facts require is that the power should be larger than our conscious selves. Anything larger will do, if only it be large enough to trust for the next step. It need not be infinite [or absolute]" (p.413). James argues that it does not follow that if God is finite instead of absolute that He should not remain the most important existence to acknowledge, if that being is maximally or sufficiently powerful enough to achieve His and our purposes. James concludes that this kind of a God is pragmatically more meaningful and closer to the biblical depiction of God than orthodox theology presents. In Process theism, Alfred North Whitehead argues that God is in some sense limited by being involved in temporal processes and therefore not absolute, but passible and mutable. Open theism argues that since the future is open and indeterminate, this must limit God's absolute knowledge. Instead of knowing all things absolutely, He has maximal

\footnotetext{
${ }^{12}$ Ostler elaborates: “Technically everybody who isn't a pantheist believes that God is finite in some respects, [even though classical Christians typically classify God as infinite] because for pantheism God is the whole of reality. The minute you say that God isn't the whole of reality you've got to delimit God in some respect and the minute you do that, He's no longer logically infinite he's now delimited in some sense. Everybody believes that God is finite in some sense who believes that God is personal. There are certain limitations for God but limitations aren't necessarily bad. For instance, limitations in cruelty, ignorance and stupidity are good things. God can't make cruelty to simultaneously be love. Limitations in and of themselves are not necessarily bad."
} 
knowledge of all things that are possible to be known at the present time. These are three movements since Smith's death that have brought ideas he held from the margins of orthodoxy and the realm of blasphemy to the theological center.

\section{Of Ethics}

By naturalizing God, Smith likewise naturalized the ethics of God. The controversy surrounding God's relation with ethics originates with Plato's Euthyphro Dilemma. Plato essentially asks, "Is something morally good because it is commanded by God, or does God command it because it is morally good?" In other words, is morality invented or discovered? Is God an engineer of morality or an expert of morality? Is morality dependent on God for its existence or does it exist independently? Leibniz noted that your answer to this question determines, "whether justice and goodness are arbitrary or whether they belong to the necessary and eternal truths about the nature of things". This is a paradox for classic Christianity, because either option holds implications that are problematic and unacceptable for the orthodox. If you pick the first horn, morality becomes arbitrary and trivial, at the whim of what God decides. If you pick the second horn, morality is then independent of God, but for the orthodox this contradicts claims of omnipotence, making God limited. For example, if Law was not created by God, then being bound by some law He has no control to alter, this limits His omnipotence, His sovereignty, and His freedom. To maintain an Alexandrian interpretation of perfection for the platonized Christian God, the first horn became the preferred position.

To defend the existence of God, many theologians have argued that morality cannot exist without a God, so if there is to be morality, there must be a God. This belief persisted for centuries in the consciousness of believers in the western world. But Dostoevsky, in the Brothers Karamazov, challenges this premise in his famous thought that, "If there is no God, anything is permitted." If upon the assumption that the only way for morality to exist it is necessary that there is a God, but in fact there is no God, then there is no morality. If there is no law-creator, then there is ultimately no law, goes the argument. If no law, no punishment and no cosmic system of accountability. As Sartre has mentioned, it was this logical sequence that birthed existentialism in an attempt to figure out how one should then live in such a godless, lawless world.

Because Smith rejects classical assumptions about God, he can uniquely respond to Dostoevsky's ideas on the subject of God's relation, not just to evil, but to ethics. Due to Smith's position that the universe and its laws are just as eternal as God (that moral and physical laws were not created by God ex nihilo), and that God is not absolute, he can favor the second horn without dilemma. Smith thus maintains that morality (of which God is an expert and example, not an engineer) is independently built into the nature of reality, making Him more of a law-giver than a law-creator. By taking the second horn without apology, Smith can dismiss Dostoevsky's comment that "if there is no God, everything is permitted". Both the premise and the conclusion become misleading in a universe that does not necessitate that morality can only exist if there is a God. With this naturalization of God's relation to ethics, Madsen observes that:

Neither God, nor law tell you what you must do. That's a fiction. They tell you what the inevitable consequences will be of what you choose to do. [That isn't coercive, that is a declaration of reality. Consequences follow on certain courses of action, even in the absence of God.] Here is an absolute that is not obsolete. Jesus is thus against selfishness and sin not because $\mathrm{He}$ is the giant spoil sport [or for other arbitrary reasons]. Just the other way around. 
$\mathrm{He}$ is against sin and selfishness because he is against despondency, and melancholy, and morbidity, and against the shrinking of our capacity for fulfillment. Having become the ultimate expert, including by experientially paying the awful price of a universal atonement, $\mathrm{He}$ is entitled to alert us to reality.

God's relation to humanity is then as a eudemonistic guide to help individuals navigate the journey of eternity in progressive fashion, to make aware the inevitable consequences of alternative choices. Givens observes that "Positing the independent existence of eternal law suggests that God is divinely perfect as a consequence of his deliberate, willful embrace of, and compliance with, those laws." In Smith's cosmology it is simple, God is not just the most powerful, $\mathrm{He}$ is the happiest, both as a result of harmonizing with eternal law. God's involvement with mankind is based in helping others to celestialize life in quality to make it worth immortalizing in quantity. This can only be accomplished by living in accordance with, as He does, ultimate natural patterns and principles that result in maximal happiness, rather than as an uncorrelated result of just superstitiously doing what $\mathrm{He}$ could've arbitrarily told you to do. Smith declared, "If you wish to go where God is, you must be like God, or in other words, possess the principles [and attributes] which God possesses" (History of the Church, 4:588). This is so because for Smith, heaven is not as much a geographical location, as it is a state of being that is attained as a consequence of accumulated decisions and one's willingness to grow (rather than a club that you can only enter upon Someone else's approval). In another instance when told that his radical thoughts would take him and his followers to hell for blasphemy, Smith remarked, "And if we go to hell, we will turn the devils out of doors and make a heaven of it. Where this people are, there is good society [because of the way they live and love each other]. What do we care where we are, if the society be good?" (History of the Church, 5:517). Smith noticed that the special ingredient that made heaven heavenly and hell a nightmare for its members wasn't due to the location itself, nor because an omnipotent being had consigned one there, but rather as a natural result of the way one lived. We are punished consequentially by our sins, not for them. If God doesn't control nor incur the natural consequences of what we do, then we selfdetermine many of the consequences we receive, and as a result, "We are our own tormentors and condemners". 13

\section{Of Mankind}

Perhaps more radical and revolutionary than Smith's new conceptions of God, was his revolutionary understanding of Mankind. These ideas radicalize Mankind's origin, nature, freedom, identity, and potential. Givens has observed that "The dominant religious views of mankind in the $19^{\text {th }}$ century saw man as created out of nothing, crippled from his birth with a depraved nature, often enjoying little or no freedom of the will, and limited in his potential by a jealous god. No wonder that by the $19^{\text {th }}$ century some societies were rebelling against kings and church alike, believing that both were an enemy to man and his eternal soul" (Givens 7). The $19^{\text {th }}$ century soul was one possessed of tension, filled with cosmic poetry expressing the limitless ambition and potentiality of Mankind on one hand, yet repressed all around with religions of limitation and despair, that instead stressed self-depravity, hellfire, and the inscrutable will and purposes of God. It had been a presumption for centuries that our souls were created ex nihilo by God upon being born in the world. Smith went against this concept and instead introduced the mind shattering idea that, "Man was also in the beginning with

\footnotetext{
${ }^{13}$ Smith also didn't believe in any sort of literal Hell-fire. Hell was a state of mind of misery, the condition of which wasn't actually a lake of fire and brimstone, but that metaphorically felt like one.
} 
God" (Doctrine and Covenants, 93:29). This idea stated that each person lived pre-mortally, or before their birth on earth, with God in heaven as a conscious individual before the world was even created.

But Smith went a step farther. "Spirits have no beginning; they existed before, they shall have no end, they shall exist after, they are eternal" (Abraham 3:18). Most are comfortable with the idea of a forever forward, but have you ever considered a forever backwards? ${ }^{14}$ What are the implications of a symmetrical eternity, instead of the dominantly depicted, lop-sided aeternitas a parte post ${ }^{15}$ ? The infinite regress of both mind and self. Each individual is eternally self-existent, with a beginningless beginning. Mind has no birthday and memory no first. In one of the most optimistic and ennobling perspectives, Smith saw Mankind as eternally existent in time, inherently innocent and embryonically divine in nature, inherently free in capacity, and infinitely perfectible in potential.

This eternalization of matter, freedom, law, and intelligence or selfhood, has many implications for theodicy upon the premise that selfhood existed pre-mortally or eternally. One of the great complaints over existence in this tumultuous world is that we are "conceived without consent, wrenched whimpering into an alien universe", subject to predicaments we are not responsible for creating yet instantly inherit upon birth (Maxwell 1). 19 $9^{\text {th }}$ century theologian Edward Beecher likewise struggled with this paradox expressing the irony that, "Pain, sickness, and death come on the human race antecedent to the development of reason. Such a constitution resembles punishment applied in anticipation of a crime... [But calling total depravity] voluntary seems like removing a difficulty by language only. In short, original, native, entire depravity is a hard doctrine to be explained... The question is, is not the present system a malevolent one? ... Evil exists. If it does prove malevolence in God, we are lost...We cannot analyze the thing" (Beecher). However, if we conceive of each individual pre-existing before mortal life, having consciously chosen to enter into such an experience, then there is no coercion involved and God is not to blame for our predicament. Our dilemma is not that we have been conceived without consent, but that we are forced to be free. William James accurately echoed Smith's conception of mankind's pre-mortal perspective when he remarked:

Suppose that the world's author put the case to you before creation, saying: "I am going to make a world not certain to be saved, a world the perfection of which shall be conditional merely, the condition being that each several agent does its own 'level best.' I offer you the choice of taking part in such a world. Its safety, you see, is unwarranted. It is a real adventure, with real danger, yet it may win through. It is a social scheme of cooperative work genuinely to be done. Will you join the procession?Will you trust yourself and trust the other agents enough to face the risk?"(290-91).

\footnotetext{
${ }^{14}$ M. F. Burnyeat, a Cambridge classical scholar, noted, "Many believe that their soul will survive death. Rather few, I imagine, believe that it also pre-existed their birth. The religions that have shaped Western culture are so inhospitable to the idea of pre-existence that you probably reject the thought out of hand, for no good reason" (Burnyeat). Other historical proponents of the pre-existence of the soul include Origen and atheistic Cambridge philosopher, John McTaggart (who found a person's premortal existence massively more intellectually compelling than a belief in its immortality.)

${ }^{15}$ Meaning a view of existence where you suddenly come into existence at a certain point in time and then live forever forward. This is a common view for those who consider afterlife a possibility. But there are other views that could be considered logically possible. What if you suddenly exist for only 100 years and then suddenly cease to exist, having never existed before and never to exist again. What if you eternally existed before but at some future moment in time you will cease to ever exist again? Smith's view is that you eternally existed before in some sense, and will eternally exist afterwards, hence that Man is really an eternal Being.
} 
Upon this premise of pre-mortality, the correct response to the complaint "I didn't ask to be born", would be "Oh yes you did", and to the frustrated query "God, why did you get me into this?", Smith would counter, "Why did you get you into this?".

Man and woman then, like God, are neither products nor producers of the universe, but self-derived, self-determined, co-eternal beings. Smith believed God's role to be as a guide to Mankind's progress to maximal happiness through the eternities, even to the extent He Himself possessed. Seeing Mankind's intelligence and infinitude as unoriginated and indestructible was an analysis of human nature that was a "stirring, compelling, and exciting synthesis that presented a spiritually hungry humankind, with a God who 'was good, and the good can never have any jealousy of anything. And being free from jealousy, He desired that all things should be as like himself as they could be" (Givens 10). God isn't anthropomorphic, rather Man is theomorphic. Within this context of cosmic christogenesis ${ }^{16}$, Smith saw the purpose of mortal life as a school and gymnasium of soul-stretching whereby humans grew experientially in a world of necessary oppositions of joy and suffering, where they would learn to choose, choose to learn, or choose to stagnate their progress.

Smith's cosmology of post-mortal life, called Eternal Progression, was no small and cramped eternity ${ }^{17}$. In this afterlife, "there are no angelic choirs passively basking in the glory of their God, but Faustian strivers endlessly seeking to shape themselves into progressively better beings, eternally working to impose order and form on an infinitely malleable cosmos...The human body and soul, then, are constituted for the amassing of experience in ever-greater variety and intensity, [secularly and spiritually]" (Givens, Rainbows over the Rain, 4). The end, or rather the ongoing, goal was in part to create a god-like life of happiness and moral elevation, to be like, and thus share in the joy experienced by, the Christ. This paradise of progression was predicated, however, upon the necessary university of mortality with its essential encounters with evil.

\section{Of Evil}

Smith's theodicy proposed an instrumentalist view of necessary suffering in the process of salvation. A perfectly (or maximally) good God is not perfectly good just for seeking to eliminate all unnecessary evil, but also for maximizing all potential happiness so far as is within His power. God's work isn't to protect people from any exposure to suffering, but to accomplish these dual desires. But God Himself is powerless to get us to the greater good of total fulfillment except through the operation of mortality, which entails suffering and freedom. To assume that God could avoid such conditions by simply forcing selfrealization upon an undeveloped, self-existent, and free agent is just as logically inconsistent as to say God could create a 4-sided triangle. Both contradict rules of logic. The latter is to misunderstand geometry as the former is to misunderstand fulfillment and freedom. Smith's view that some suffering is necessary and unavoidable, yet instrumental to achieve certain greater goods, is comparable to paying the essential, but beneficial price of working out at a gym to maintain or promote health. There simply isn't a way to buy muscles off Amazon and

\footnotetext{
${ }^{16}$ From Teilhard de Chardin, French philosopher and Jesuit priest, this is the idea that the ultimate purpose of the cosmos is to evolve people to become exactly like Jesus Christ in attributes of maximal love, goodness, knowledge, and capacity (Lyons 39). For me this idea is identical to ideas like theosis, but specifies concretely Smith's intented meaning of the type of being one could potentially become by harmonizing with His teachings, being changed by the atonement, and being refined through the process of mortality and beyond.

${ }^{17}$ This is an allusion to G.K. Chesterton: "There is such a thing as a small and cramped eternity. You may see it in many modern religions" (Chesterton, Orthodoxy, 12).
} 
have them shipped to you. Nor can virtue be developed by simply reading about it in a library. Some things can only be developed experientially. For example, physical fitness is never achieved, nor any worthwhile accomplishment, without any degree of suffering experienced in the process. Suffering then is not necessarily purposeless or trivial, it is meaningful if it can reap growth and transform us positively. The only way for physical growth in our muscles is through stress, pain, and sacrifice. Similarly in God's sanctifying process, there is no other way. The only way for soul-stretching and the kind of development that leads to being fully Christlike is upon this same principle of experiencing dynamic tension with genuine distress and opposition. Madsen notes that,

It isn't sufficient to ask, 'Could God have prevented the blindness that afflicts that newborn child?' 'Could God have healed such and such a person who was born without a spine?' 'Could God reverse the ravages of disease in those who are suffering from all these forms of terminal cancer?' Of course, He has the power to do those things! Then, why doesn't He? Ah, because we don't ask the right question, which is, 'Can He do compossible things? Can He achieve the purposes of mortality in our lives and at the same time eradicate all suffering and evil? And the answer is, 'No, He cannot'.

The value of Smith's instrumental view of evil can only arise, however, from the premises he makes about the motives and capacities of God, Mankind, and the universe. This same explanation is unavailable to the classical God whose purposes for creating mankind and mortality are covered in mystery. Why is there man at all? What is man being saved for? Is there no other way for an omnipotent God to accomplish whatever his purposes may be without putting us through such a painful process? As Mark Twain observed, it is troubling to say evil and suffering in this life is really essential and instrumental if the purpose of life is (as many classical Christians hold) only to selflessly glorify a God who "gave his angels eternal happiness unearned, yet requires his children to earn it; gave his angels painless lives, yet cursed his children with biting miseries and maladies of mind and body... Who could have made every one of them happy, yet never made a single happy one; who made them prize their bitter life, yet stingily cut it short". Where is the justification for creating people in a world of havoc when you omnipotently could have created them happy in heaven? Perhaps there are reasons, but scripture is silent on the matter. As we have before mentioned, Givens notes that the consequence of all this was a, "traditional theology that confines itself to defining the terms and conditions of a very limited concept of salvation, of a soul of unknown beginnings, from an evil of unknown origin, to prepare for a future of unknown nature, all in accordance with the inscrutable will of a God who is beyond human comprehending".

But what of unnecessary suffering, the type which the universe would be, all things considered, better without? This is the type of suffering that you or God have the power to eradicate and to do so would not interfere with achieving other objectives you have for allowing greater goods. Unnecessary suffering does exist in addition to potentially instrumental suffering. Not all pain necessarily leads to improvement, hence pain need not be sought after, but rather should be sought to be eradicated in its needless forms rather than wishfully justified with illusory meaning. Smith's God allows instrumental suffering to occur, but does all in His power to eliminate unnecessary suffering that occurs in the world. ${ }^{18}$

Can there be self-fulfillment without a self? Can there be a self without autonomously free self-determination? Can there be self-determination without alternative choices? Are

\footnotetext{
${ }^{18} \mathrm{Sin}$ is a type of self-inflicted unnecessary suffering, hence why there is so much emphasis from God on eliminating it from the world.
} 
genuine alternatives possible without genuine oppositions? If selves cannot act independently for themselves, then there is no existence of a genuine self. ${ }^{19}$ Existence of genuine identity depends on genuine freedom which depends on genuine oppositions to choose from. Otherwise we regress from being subjects who act to objects acted upon (Doctrine and Covenants 93:30). Self-fulfillment emerges as a potential option by an eternal cosmos of natural opposition in all things and in all possible choices (the good and the bad, the bitter and the sweet). Smith saw this law of opposites as an irrevocable, yet valuable condition inherently built into the universe's structure of possibilities. Encountering oppositions, such as suffering, can be instrumentally beneficial because they allow one to become acutely aware of certain truths and develop certain moral virtues that otherwise could not be acquired. "By proving contraries, truth is made manifest" (Smith, History of the Church 6:248). Further explaining how, Ostler notes:

It is true that we do not need to be unkind in order to be kind; however, it does not follow that we could know and appreciate what kindness is unless we had some idea of what it would be like for persons not to be kind. [While it is not the case] that every good always requires an offsetting evil to exist (an ontological issue), opposition is essential to our knowledge of both good and evil (an epistemological issue). Tasting the bitterness of evil in the world affords us an opportunity to know and learn to prize what otherwise we could not appreciate. There are virtues, then, that require opposition in order to be realized. Lehi, an ancient Hebrew prophet of the Book of Mormon, argues that God's purpose in creating humankind was to make it possible for us to know joy. As a condition to experiencing this joy, it is necessary to be able to choose between good and evil and to experience both bitter and sweet. While it is not necessary to be unkind to be kind, it is necessary to have genuine choices among good and evil alternatives to be free in a morally significant sense. Indeed, F. R. Tennant has argued that our concept of good has meaning only when related to concepts of opposition, such as temptation, courage, and compassion. Courage is developed through facing real challenges, compassion comes about as a response to the presence of pain and suffering, and temptation exists only where there is the possibility of choosing evil (Ostler 209).

Much of the unnecessary evil and suffering in the world are moral evils that derive from the essential freedom of Mankind, whether by self-inflicting harm or being harmed by others, intentionally or accidentally. While freedom is an essential element for fulfillment, the extent of Mankind's moral depravity is not, since by ex nihilo creation and omnipotence, the classical God could have created any type of persons He wanted. Notwithstanding this, He still created people who He knew by absolute foreknowledge would be inclined to abuse this freedom and cause unnecessary suffering in so great an amount. Twain found it absolutely puzzling why an omnipotent God, "who could make good children as easily as bad, preferred to make bad ones". By creating mankind ex nihilo, God is responsible for determining where to place mankind's degree of moral sensitivity between the two extremes of moral perfection and moral depravity. Paulsen and Ostler explain why the classical God's particular placement along the spectrum of moral sensitivity is unjustifiable:

There is no reason why God could not have made human beings significantly more virtuous than they are. Why not, for example, give them some significant reduction in their sometimesoverwhelming tendencies toward selfishness that lead to violence, rape, stealing, and other such behaviors? Why could God not have increased their natural aversion to violence? Why could he not have made them more morally sensitive or more intelligent and compassionate so as to see the consequences of their actions on others? Such creative choices on God's part might have narrowed the options over which mortals' own choices might range, but such limitations

\footnotetext{
${ }^{19}$ Moral actions are most significant not when we do what is right, but when we choose to do what is right.
} 
are entirely compatible with a strong notion of self-determinative freedom and with God's soulmaking objectives (Ostler and Paulsen).

Known more specifically as the evidential problem of evil, this begs the question not just why does evil exist, but why quantitatively and qualitatively so much of it unnecessarily exists. Why does it exist in such unnecessary extremes in diversity and intensity? Classical theologians have long responded that evil must exist in some respects for the will to be free. True, but this does nothing to solve the evidential problem of evil. The problem is not that the will is free, but that the will was created by God to be free and capable enough to the point of committing horrifying acts that are not instrumental to God's purposes. If by ex nihilo God is responsible for mankind's moral sensitivity, inclinations, and tendencies, surely God could have prevented extremes like Hitlers and Stalins from arising, or the prevalence of other terrible crimes, without betraying freedom.

A perfectly good and powerful God will eliminate all unnecessary evil. It is unnecessary that our human nature be as morally deficient as it is for freedom to exist. It does not follow that the existence of moral weakness or inclinations to violence or other vices of any kind are incompatible with the goodness of God. It is problematic, however, that a God who claims absolute creation and absolute power could have created us to a more moral degree, thus eliminating unnecessary atrocities while not overriding our freedom, but didn't. The classical God is thus left unjustified for allowing various extremes of unnecessary forms of suffering from moral and natural evils that are in His power to eradicate.

For Smith, however, "God never had the option of creating persons from nothing with just the characteristics he wanted" (Paulsen and Ostler). Individuals are uncreated and eternal. God never gave us our freedom, we instead eternally possessed self-determinacy. God, then, is not transitively responsible for our morally extreme choices. ${ }^{20}$ Our level of moral sensitivity was (and is) self-determined and enhanced at our own pace. God can't then determine the extent of one's moral sensitivity, but helps one advance from wherever they currently reside along that spectrum. Smith's God is thus justified in allowing evil to exist for Himself to (1) remain consistent with eternal individuals' free will, (2) to remain consistent with eternal laws, and (3) to not prevent us from greater possession of joy in quantity and quality (Ostler, see Formal Proof in Works Cited).

Though possessing a formal education equivalent to that of a third grader, the uneducated and untrained Joseph Smith proposed a unique philosophy that has been recognized, even by Smith's critics such as Carl Mosser of Notre Dame, as a valid solution to the logical, evidential, moral, natural, and existential problems of evil, one of history's most profound paradoxes (Mosser, 217). In so doing, Smith revealed a God who answered to Ivan's criticisms rationally, morally, and aesthetically.

\section{Of Meaning}

Albert Camus famously began The Myth of Sisyphus with the line, "There is but one truly serious philosophical problem, and that is suicide." ${ }^{21}$ The most important question of philosophy is, "Is life worth living?" This is one of the ultimate questions upon which the

\footnotetext{
${ }^{20}$ Even if evil were to be attributed to Satan, God can't be blamed for Satan's influence, since He didn't even create him. Lucifer, an eternally existent being, created or chose to become Satan. This is another problematic issue with classical orthodoxy that I will avoid to investigate in this paper.

${ }^{21}$ While Camus would argue that while he accepted that life was absurd, he would argue that that didn't justify suicide. To do so is to let death and life have dominion over you. One must instead rebel, create meaning, and live in the absurd in heroic rejection of death.
} 
problem of evil is founded. Here in lies the significant intersection between theodicy and existentialism. While Ivan and Joseph join in rejecting the God of Christian orthodoxy, it is in this that they most clearly diverge with distinct cost/benefit analyses of life and salvation.

Having inherited a neo-platonic set of premises of an absolutistic God, Calvinistic and Augustinian views of a depraved, fallen mankind under the bondage of original sin, and existentialist views of the apparent absurdity of life, Ivan rationally rejects the purposes of God, unable to reconcile His supposed goodness with the torture of children. Ivan would have rejected James's invitation (to join the procession of mortality) in rebellion to an immoral system of salvation, favoring with his grand inquisitor security from mortality, rather than freedom to participate in it.

Some thus exaggerate suffering enough to eventually conclude that life is meaningless. But if existence is truly absurd, it can't be meaningful to say so (Madsen). Saying one lives in an absurd world is really to say that one knows that it should be different. For all their claims of meaninglessness, most existentialists ironically seem pretty happy when they win literary prizes. Does celebrating despair, then, deserve to pass as heroism? Or is this demonstration of supposed raw honesty actually a sophisticated form of cowardice, a hallucination of sick minds incapable of seeing meaning? (That is a paper for another day.)

In stark contrast to Ivan, Smith reveals a material, non-absolute God who is justified in allowing evil to allow individuals to achieve maximal joy. Upon these notions of soulmaking and christogenesis, suffering (instead of making life meaningless) can actually endow life with majestic meaning.

To be or not to be? In contrast to Hamlet and Camus, this is not the question. For Smith, no one can choose to be or not to be. What is the question then? The question is not one of being, but of becoming. To become more or not to become more? This is the question that eternal beings, void of the possibility of non-existence, must answer (Madsen).

\section{The God who Weeps}

To Smith, God likewise wrestles with evil. In one of Smith's revelatory recoveries of an ancient religious text, The Book of Moses, the prophet Enoch is taken to heaven and sees a startling sight: God weeping. Enoch is baffled that the God he had always envisioned to be so almighty as to be detached from and unfazed by the acute sufferings of this world, a God who had created the infinite universe filled with galaxies and planets, to actually be touched by the everyday pains we, grains of sand in this cosmic beach, feel. Enoch recounts these feelings to a now more humanized God, asking Him how it is possible that He can cry and why He should at all? God explains His dilemma. He sees the consequential misery that awaits, not mere creations, but His literal children, and he wishes to help them to alleviate their sorrows, but they reject His attempts to do so. Knowing that His children will suffer unnecessarily so, why not weep? Especially over those prodigals who don't return home? God's motivation for involvement with the human race is not as a moral police officer constantly looking to catch lawbreakers, a judge yearning to punish anyone who sins, or a divine referee trying to tag us off on third base (Holland). Rather He is interested as a father trying to alleviate all unnecessary suffering as is possible to allow maximum joy.

Smith's insights introduced a weeping God, who even in the eternities suffered with the sorrow of others, an image of God which emphasizes his infinite empathy and vulnerability, rather than the typical emphasis of God's infinite power. This insight converts Aristotle's image of God from the "Unmoved Mover" into the "Most Moved Mover". When 
flooding the earth, rather than doing so in rage, God wept as he did so, His tears corresponding to the rain of the flood, for the misery of His children ${ }^{22}$.

But Smith's Christ, though involved and personal like the Father, does not get away with mere spectator suffering. He forever leaves the realm of spectator and fully becomes the ultimate participator and expert of the human experience. Smith's conception of Atonement, like every other theologian, is undeveloped and unclear in its specific mechanics. Smith was clear, however, that the figure Jesus Christ was the keystone in the plan of eternal progression and in the christogenic conversion of undeveloped and handicapped souls to ever improving Christlike beings of infinite capacities for goodness and light. Unlike in other theologies, Smith's Christ does not simply atone for the sins of the world, but in addition, suffers all the jots and tittles of the universe's (not just this planet's) suffering. In this multidimensional atonement, the universal Christ infuses the entire human history of experience into his being ${ }^{23}$. This process perfects him in capability for his role as Savior and Judge. Both these roles are revolutionized as Christ gains perfect experiential knowledge of our experiences and is now a perfect expert on how to heal and make whole any experience. Now knowing firsthand the ultimate brokenness of Mankind, He knows how to justly and mercifully judge, and most especially, pardon. This Atonement expands the suffering of Jesus from simply suffering the punishment for our sins, to having duplicated in his senses the exact pains, doubts, fears, depressions, and deaths that have occurred or could in the universe.

The dark and absurd depths that Christ would have had to descend to in Smith's vision of cosmic Atonement aligns with remarks from Albert Camus (who in this case was ironically following Dostoevsky) when he said that Christ could only really incarnate the 'human drama' if he shared that which marks it as most absurd: sharing with Mankind a genuine belief and a genuine fear as he was suffering, that in reality there would be no resurrection, that he was being tortured and killed for no reason, that it was all meaningless, and that his whole mission that he had lived and died for was all a lie. Christ would have to descend below all things. Whether He weeps in sympathy by observation or by pure empathy in the shared, duplicated experience of suffering, the Jesus of Joseph Smith is one who is not only not limited to atoning only for sins, nor sparred from the accumulated suffering and evil of the universe, $\mathrm{He}$ is the most exposed to its exquisiteness. The crux of theodicy and the problem of evil centers on the case of Christ in the tragic irony that The Most Innocent suffers the most, suffers as if guilty of everything. Joseph ultimately concludes that the Christ, though not the source of our suffering, is the source to overcome evil and suffering, instrumentally converting it into one's moral improvement and an acquisition of joy in greater depth.

Whence then cometh Evil? While some like Jacob and Ivan prefer to wrestle against God, others like Smith and Madsen see the wrestle to be with God against evil, rather than against God himself. Shifts in the intellectual climate over the last centuries have sparked divergent reactions to this issue, almost all of some revolutionary response to the accumulated degeneracies of past generations. Even with human advancements, such as in

\footnotetext{
${ }^{22}$ God's capacity to weep, does not reduce or weaken Him, it instead magnifies Him as a being worthy of worship.

${ }^{23}$ Jesus suffered for the victims, as well as the victimizers and the villains, with incomprehensible grace, like Hugo's priest to Valjean. This was, in part, to eternalize and equalize the possibility of redemption and fulfillment upon the condition of every person's will and effort to change. Smith said, "There is never a time when the spirit is too old to approach God" (Smith 191).
} 
technological innovations and humanitarian efforts, the problem of evil and suffering is far from being exiled from our world. With new insights such as those discussed in this paper, evil will ever evaporate as a philosophical conundrum. Yet regardless of our reconciliations with reason, we must all confront this existential Goliath experientially. With so much needless suffering still scarring our world and seared in our memories, our journey with Jacob (or Sisyphus?) is an uphill climb. The wrestle with this weeping God goes on, some finishing the long dark night returning the ticket, others in sacred, fulfilling embrace.

\section{Formal Proof of Joseph Smith's Theodicy (Ostler):}

1. God is almighty, omniscient, all-good, and exists.

2. God is conditioned by the existence of coeternal realities such as:

a. Intelligences (necessarily existing selves).

b. Chaotic mass/energy.

c. Moral principles.

d. Physical laws defining time, space and matter.

3. God is almighty if he can bring about the optimal realization of potential among states of affairs (i.e., states of affairs consistent with there being other ontological realities).

4. A perfectly good being prevents all the evil and promotes all the good it can without thereby preventing a greater good.

5. Moral evils occur and God justifiably allows them because:

a. Human nature is uncreated (2a).

b. Humans are inherently self-determining and categorically free (2a).

c. Humans are morally imperfect and potentially perfectible (2a, 2c).

d. God's purpose in creation is to provide the opportunity for intellectual and moral development of persons $(2 \mathrm{a}, 4)$.

e. Moral opposition is necessary to moral development (2a, 2c).

f. God did not create human nature either virtuous or depraved (5a, 5b).

g. Humans sometimes choose evil $(5 b, 5 c)$.

h. God is justified in not contravening human evil choices $(3,4,5 \mathrm{~d}, 5 \mathrm{e})$.

6. Natural evils occur and God is not blameworthy for them because;

a. Chaotic mass/energy is uncreated ( $2 b)$.

$\mathrm{b}$. The laws governing mass/energy are eternal and independent of God (2b, 2d).

c. Some of these laws require that mass/energy be organized on causal principles (2d).

d. Adverse physical circumstances may enhance moral and intellectual development of intelligences $(2 \mathrm{a}, 2 \mathrm{c}, 5 \mathrm{c})$.

e. The nature of causal principles is such that many indiscriminant natural evils occur $(6 a, 6 b, 6 c)$.

f. God may justifiably allow some natural evils $(3,4,6 \mathrm{~d})$.

7. Whatever evils occur are:

a. Unpreventable by God consistent with individual autonomy.

b. Unpreventable by God without thereby preventing a greater good.

c. Unpreventable by God consistent with eternal laws. 


\section{Properties of the classical God of Christianity}

The classical God of Christianity is utterly distinct from all realities other than Himself and who possesses all of the following characteristics:

- Causal Ultimacy, being the temporal and/or metaphysical source of all realities other than divine nature itself;

- Complete Sovereignty, or unrivaled (incontestable) power and dominion over all reality;

- Eternity, being timeless and immutable and thus outside of space and time; simple, not having a composite nature, not being comprised of parts, hence, being literally incorruptible.

- God participates in no genus or species, thus exists as Pure Being;

- He possesses the famous "Omni's":

- Omniscience, having complete, infallible knowledge of everything that can be known, including the future;

- Omnipotence, being capable of precipitating (causing) any event or situation the bringing about of which (a) is not logically impossible and (b) is not incompatible with other attributes of the divine nature;

- Omnipresence or immutability (changelessness), existing outside and independently of the stream of temporal events and thus ever present; and finally,

- Omnibenevolence, being absolutely and infallibly good, incapable of moral error, malice, or wrongdoing.

- Other properties include: Impassibility, Aseity, Goodness, Graciousness, Holiness, Immanence, Impeccability, Incomprehensibility, Incorporeality, Infinity, Jealousy, Love, Mission, Mystery, Oneness, Providence, Righteousness, Simplicity, Transcendence, Trinity, Veracity, Wrath.

- God is also unique in that She or He possesses the foregoing attributes in ways that could not conceivably be duplicated or even remotely imitated (McLachlan).

\section{Works Cited:}

[1] Atfield, Robin. "The God of Religion and the God of Philosophy", Religious Studies, vol, 9.

[2] Barr, James. "Holy Scripture: Canon, Authority, Criticism" (Philadelphia: Westminster, 1983), 24, 25; emphases in original.

[3] Barton, John. "People of the Book? The Authority of the Bible in Christianity" (London: SPCK, 1993), 24.

[4] Beecher, Charles. "Life of Edward Beecher," unpublished manuscript in Illinois State College Library.

[5] Berger, Peter. (2014). "Redeeming Laughter: The Comic Dimension of Human Experience" (2, reprint ed.). Walter de Gruyter. p. 88

[6] Bloom, Harold. "The American Religion". Chu Hartley Publishers, 2006. p.95

[7] Burnyeat, M. F. "Other Lives," London Review of Books 29.4 (22 February 2007).

[8] Camus, Albert. "The Myth of Sisyphus: and Other Essays". A.A. Knopf, 1975.

[9] Chesterton, G.K. "Orthodoxy". Simon and Brown, 2018. p. 12

[10] Dostoyevsky, Fyodor. "The Brothers Karamazov". CreateSpace Independent Publishing Platform, 2017.

[11]Ferre, Nels F.S. "The Universal World" (Philadelphia: Westminster Press), 1969, p. 91

[12] Gates, David. "The Napoleonic Wars 1803-1815” (NY: Random House, 2011). Joshua Picaro Cates.

[13] Givens, Terryl. "Lightning out of Heaven." 2005.

[14] Givens, Terryl. "Rainbows Over the Rain: The Gospel of Superabundance." BYU Hawaii. 2009, Hawaii. 
[15] Givens, Terryl, and Fiona Givens. "The God Who Weeps: How Mormonism Makes Sense of Life." Ensign Peak, 2012.

[16] Givens, Terryl and Richard Bushman. "No Small and Cramped Eternities." Parallels and Convergences: Mormon Thought and Engineering Vision, edited by A. Scott Howe, Greg Kofford Books, 2012, pp. 1-8.

[17] Greenberg, Irving (1998). "The Jewish Way: Living the Holidays", p.253, Jason Aronson, Incorporated.

[18] Holland, Jeffrey. "Look to God and Live." General Conference. October 1993, Utah.

[19] James, William. "Pragmatism". (1975) p. 139.

[20] James, William. "Varieties of Religious Experience: a Study in Human Nature". NOVA, 2019.

[21] Kolitz, Zvi. (1993). "Confrontation: The Existential Thought of Rabbi J.B. Soloveitchik". KTAV Publishing House. p. 50.

[22] Lactantius, Lucius Caecilius Firmianus. "Divine Institutiones." pp. 494-494.

[23]Leloir, Alexander. Jacob Wrestling the Angel. 1865, Museum of Modern Art, New York City, New York, U.S.A.

[24] Leibniz, Gottfried. 1702, "Reflections on the Common Concept of Justice".

[25] Lynds, Peter. (2006) "On a finite universe with no beginning and no end".

[26] Lynds, Peter. (2012) "Why there is something rather than nothing: The finite, infinite and eternal".

[27]Lyons, J. A. (1982). "The Cosmic Christ in Origen and Teilhard de Chardin: A Comparative Study". Oxford: Oxford University Press. p. 39.

[28] MacMullen, Ramsay. "Voting about God in Early Church Councils." Yale University Press, 2006.

[29] Madsen, Truman G. "Eternal Man". Deseret Book, 2013.

[30] Madsen, Truman G. "Timeless Questions, Gospel Answers". 2002.

[31] Maxwell, Neal A. "By the Gift and Power of God." Echoes of the Book of Mormon, Foundation for Ancient Research, and Mormon Studies, 2002, pp. 1-11.

[32] McDonald, Lee M. and Paulsen, David "The Formation of the Christian Biblical Canon", rev. and enl. (Peabody, Mass.: Hendrickson, 1995), esp. 268-76.

[33] McLachlan, James, Givens, Terryl, and Barlow, Phillip. "The Oxford Handbook of Mormonism." Oxford University Press, 2015.

[34] McMurrin, Sterling, "Some Distinguishing Characteristics of Mormon Philosophy." Sunstone (March 1993).

[35] McMurrin, Sterling. "The Theological Foundations of the Mormon Religion." Salt Lake City: University of Utah Press, 1964

[36] Mosser, Carl, and Paul Owen. "Can the Real Problem of Evil be Solved?". The New Mormon Challenge: Responding to the Latest Defenses of a Fast-Growing Movement. Zondervan, 2002. p. 217.

[37] Nibley, Hugh "The Message of the Joseph Smith Papyri: An Egyptian Endowment" (Salt Lake City: Deseret Book, 1975), 243.

[38] Ostler, Blake and David Paulsen. "Sin, Suffering, and Soul-Making: Joseph Smith on the Problem of Evil." Revelation, Reason, and Faith: Essays in Honor of Truman G. Madsen, edited by Truman G. Madsen et al., Brigham Young University, 2002.

[39] Ostler, Blake. "Exploring Mormon Thought: The Attributes of God". (Salt Lake City: Kofford Books, 2001)

[40] Ostler, Blake. (2003) "Evil: A Real Problem for Evangelicals". Review of Books on the Book of Mormon 1989-2011: Vol. 15 : No. 1, Article 13.

[41] Ostler, Blake. Formal Proof of Joseph Smith's Theodicy. "Mormon Concept of God". Dialogue, 1984. p. 87-88.

[42] Ostler, Blake. "The Fallacy of Fundamentalist Assumptions". FAIR, 2005.

[43]Pearce, David (1995). "The Hedonistic Imperative". hedweb.com.

[44] Rahner, Karl "Visions and Prophecies", Inquiries p. 106

[45] Roberts, B. H., ed. (1950), History of The Church of Jesus Christ of Latter-day Saints p. 302-17

[46] Rushdie, Salaman. "Is Nothing Sacred?".” The Broadview Anthology of Expository Prose, edited by Don LePan et al., Broadview Press, 2017, p. 360-368.

[47] Samuelson, Norbert, "That the God of the Philosophers is not the God of Abraham, Isaac, and Jacob." Harvard Theological Review 65 January 1972 1-27.

[48] Sanders, James A. "The Issue of Closure in the Canonical Process," in The Canon Debate, ed. Lee Martin McDonald and James A. Sanders (Peabody, Mass.:Hendrickson, 2002), 252. 


\section{International Journal of Theology, Philosophy and Science \\ No. 5, Year 3/2019 \\ https://ijtps.com/ \\ ISSN 2601-1697, ISSN-L 2601-1689}

[49] Smith, Joseph. "The Book of Abraham”. Church of Jesus Christ of Latter-Day Saints, 2006.

[50] Smith, Joseph "The Book of Moses". Church of Jesus Christ of Latter-Day Saints, 2006.

[51] Smith, Joseph. "Doctrine and Covenants". Church of Jesus Christ of Latter-Day Saints, 1998.

[52] Smith, Joseph. "Teachings of the Prophet Joseph Smith", ed. Joseph Fielding Smith, p. 191 Salt Lake City, 1938.

[53] Twain, Mark A. “The Mysterious Stranger”. Harper, 1922

[54] VanderKam, James C. "Questions of Canon Viewed through the Dead Sea Scrolls," in McDonald and Sanders, Canon Debate, 92.

[55] Young, Brigham. August 11, 1872, “Journal of Discourses” 27 vols. (Liverpool, England: Franklin D. Richards and Samuel W. Richards, 1851- 86; rpt. Salt Lake City, 1974), 15:127.

\section{Brothers Karamazov Dialogue}

"I must make one confession" Ivan began. "I could never understand how one can love one's neighbours. It's just one's neighbours, to my mind, that one can't love, though one might love those at a distance. I once read somewhere of John the Merciful, a saint, that when a hungry, frozen beggar came to him, he took him into his bed, held him in his arms, and began breathing into his mouth, which was putrid and loathsome from some awful disease. I am convinced that he did that from 'self-laceration,' from the self-laceration of falsity, for the sake of the charity imposed by duty, as a penance laid on him. For anyone to love a man, he must be hidden, for as soon as he shows his face, love is gone."

"Father Zossima has talked of that more than once," observed Alyosha; "he, too, said that the face of a man often hinders many people not practised in love, from loving him. But yet there's a great deal of love in mankind, and almost Christ-like love. I know that myself, Ivan."

"Well, I know nothing of it so far, and can't understand it, and the innumerable mass of mankind are with me there. The question is, whether that's due to men's bad qualities or whether it's inherent in their nature. To my thinking, Christ-like love for men is a miracle impossible on earth. He was God. But we are not gods. Suppose I, for instance, suffer intensely. Another can never know how much I suffer, because he is another and not I. And what's more, a man is rarely ready to admit another's suffering (as though it were a distinction). Why won't he admit it, do you think? Because I smell unpleasant, because I have a stupid face, because I once trod on his foot. Besides, there is suffering and suffering; degrading, humiliating suffering such as humbles me-hunger, for instance-my benefactor will perhaps allow me; but when you come to higher suffering - for an idea, for instance-he will very rarely admit that, perhaps because my face strikes him as not at all what he fancies a man should have who suffers for an idea. And so he deprives me instantly of his favour, and not at all from badness of heart. Beggars, especially genteel beggars, ought never to show themselves, but to ask for charity through the newspapers. One can love one's neighbours in the abstract, or even at a distance, but at close quarters it's almost impossible. If it were as on the stage, in the ballet, where if beggars come in, they wear silken rags and tattered lace and beg for alms dancing gracefully, then one might like looking at them. But even then we should not love them. But enough of that. I simply wanted to show you my point of view. I meant to speak of the suffering of mankind generally, but we had better confine ourselves to the sufferings of the children. That reduces the scope of my argument to a tenth of what it would be. Still we'd better keep to the children, though it does weaken my case. But, in the first place, children can be loved even at close quarters, even when they are dirty, even when they are ugly (I fancy, though, children never are ugly). The second reason why I won't speak of grown-up people is that, besides being disgusting and unworthy of love, they have a compensation - they've eaten the apple and know good and evil, and they have become 'like 
gods.' They go on eating it still. But the children haven't eaten anything, and are so far innocent. Are you fond of children, Alyosha? I know you are, and you will understand why I prefer to speak of them. If they, too, suffer horribly on earth, they must suffer for their fathers' sins, they must be punished for their fathers, who have eaten the apple; but that reasoning is of the other world and is incomprehensible for the heart of man here on earth. The innocent must not suffer for another's sins, and especially such innocents! You may be surprised at me, Alyosha, but I am awfully fond of children, too. And observe, cruel people, the violent, the rapacious, the Karamazovs are sometimes very fond of children. Children while they are quite little - up to seven, for instance - are so remote from grown-up people they are different creatures, as it were, of a different species. I knew a criminal in prison who had, in the course of his career as a burglar, murdered whole families, including several children. But when he was in prison, he had a strange affection for them. He spent all his time at his window, watching the children playing in the prison yard. He trained one little boy to come up to his window and made great friends with him... You don't know why I am telling you all this, Alyosha? My head aches and I am sad."

"You speak with a strange air," observed Alyosha uneasily, "as though you were not quite yourself."

\section{The Inhumanity of Man}

"By the way, a Bulgarian I met lately in Moscow," Ivan went on, seeming not to hear his brother's words, "told me about the crimes committed by Turks and Circassians in all parts of Bulgaria through fear of a general rising of the Slavs. They burn villages, murder, outrage women and children, they nail their prisoners by the ears to the fences, leave them so till morning, and in the morning they hang them - all sorts of things you can't imagine. People talk sometimes of bestial cruelty, but that's a great injustice and insult to the beasts; a beast can never be so cruel as a man, so artistically cruel. The tiger only tears and gnaws, that's all he can do. He would never think of nailing people by the ears, even if he were able to do it. These Turks took a pleasure in torturing children,- - too; cutting the unborn child from the mothers womb, and tossing babies up in the air and catching them on the points of their bayonets before their mothers' eyes. Doing it before the mothers' eyes was what gave zest to the amusement. Here is another scene that I thought very interesting. Imagine a trembling mother with her baby in her arms, a circle of invading Turks around her. They've planned a diversion: they pet the baby, laugh to make it laugh. They succeed, the baby laughs. At that moment a Turk points a pistol four inches from the baby's face. The baby laughs with glee, holds out its little hands to the pistol, and he pulls the trigger in the baby's face and blows out its brains. Artistic, wasn't it? By the way, Turks are particularly fond of sweet things, they say."

"Brother, what are you driving at?" asked Alyosha.

"I think if the devil doesn't exist, but man has created him, he has created him in his own image and likeness."

"Just as he did God, then?" observed Alyosha. "'It's wonderful how you can turn words,' as Polonius says in Hamlet," laughed Ivan. "You turn my words against me. Well, I am glad. Yours must be a fine God, if man created Him in his image and likeness. You asked just now what I was driving at. You see, I am fond of collecting certain facts, and, would you believe, I even copy anecdotes of a certain sort from newspapers and books, and I've already got a fine collection. The Turks, of course, have gone into it, but they are foreigners. I have specimens from home that are even better than the Turks. You know we prefer beating-rods 
and scourges - that's our national institution. Nailing ears is unthinkable for us, for we are, after all, Europeans. But the rod and the scourge we have always with us and they cannot be taken from us. Abroad now they scarcely do any beating. Manners are more humane, or laws have been passed, so that they don't dare to flog men now. But they make up for it in another way just as national as ours. And so national that it would be practically impossible among us, though I believe we are being inoculated with it, since the religious movement began in our aristocracy. I have a charming pamphlet, translated from the French, describing how, quite recently, five years ago, a murderer, Richard, was executed-a young man, I believe, of three and twenty, who repented and was converted to the Christian faith at the very scaffold. This Richard was an illegitimate child who was given as a child of six by his parents to some shepherds on the Swiss mountains. They brought him up to work for them. He grew up like a little wild beast among them. The shepherds taught him nothing, and scarcely fed or clothed him, but sent him out at seven to herd the flock in cold and wet, and no one hesitated or scrupled to treat him so."

"Quite the contrary, they thought they had every right, for Richard had been given to them as a chattel, and they did not even see the necessity of feeding him. Richard himself describes how in those years, like the Prodigal Son in the Gospel, he longed to eat of the mash given to the pigs, which were fattened for sale. But they wouldn't even give that, and beat him when he stole from the pigs. And that was how he spent all his childhood and his youth, till he grew up and was strong enough to go away and be a thief. The savage began to earn his living as a day labourer in Geneva. He drank what he earned, he lived like a brute, and finished by killing and robbing an old man. He was caught, tried, and condemned to death. They are not sentimentalists there. And in prison he was immediately surrounded by pastors, members of Christian brotherhoods, philanthropic ladies, and the like. They taught him to read and write in prison, and expounded the Gospel to him. They exhorted him, worked upon him, drummed at him incessantly, till at last he solemnly confessed his crime. He was converted. He wrote to the court himself that he was a monster, but that in the end God had vouchsafed him light and shown grace. All Geneva was in excitement about him-all philanthropic and religious Geneva. All the aristocratic and well-bred society of the town rushed to the prison, kissed Richard and embraced him; 'You are our brother, you have found grace.' And Richard does nothing but weep with emotion, 'Yes, I've found grace! All my youth and childhood I was glad of pigs' food, but now even I have found grace. I am dying in the Lord.' 'Yes, Richard, die in the Lord; you have shed blood and must die. Though it's not your fault that you knew not the Lord, when you coveted the pigs' food and were beaten for stealing it (which was very wrong of you, for stealing is forbidden); but you've shed blood and you must die.' And on the last day, Richard, perfectly limp, did nothing but cry and repeat every minute: 'This is my happiest day. I am going to the Lord.' 'Yes,' cry the pastors and the judges and philanthropic ladies. 'This is the happiest day of your life, for you are going to the Lord!' They all walk or drive to the scaffold in procession behind the prison van. At the scaffold they call to Richard: 'Die, brother, die in the Lord, for even thou hast found grace!' And so, covered with his brothers' kisses, Richard is dragged on to the scaffold, and led to the guillotine. And they chopped off his head in brotherly fashion, because he had found grace. Yes, that's characteristic."

"That pamphlet is translated into Russian by some Russian philanthropists of aristocratic rank and evangelical aspirations, and has been distributed gratis for the enlightenment of the people. The case of Richard is interesting because it's national. Though to us it's absurd to cut off a man's head, because he has become our brother and has found grace, yet we have our 
own specialty, which is all but worse. Our historical pastime is the direct satisfaction of inflicting pain. There are lines in Nekrassov describing how a peasant lashes a horse on the eyes, 'on its meek eyes,' everyone must have seen it. It's peculiarly Russian. He describes how a feeble little nag has foundered under too heavy a load and cannot move. The peasant beats it, beats it savagely, beats it at last not knowing what he is doing in the intoxication of cruelty, thrashes it mercilessly over and over again. 'However weak you are, you must pull, if you die for it.' The nag strains, and then he begins lashing the poor defenceless creature on its weeping, on its 'meek eyes.' The frantic beast tugs and draws the load, trembling all over, gasping for breath, moving sideways, with a sort of unnatural spasmodic action-it's awful in Nekrassov. But that only a horse, and God has horses to be beaten. So the Tatars have taught us, and they left us the knout as a remembrance of it. But men, too, can be beaten. A welleducated, cultured gentleman and his wife beat their own child with a birch-rod, a girl of seven. I have an exact account of it. The papa was glad that the birch was covered with twigs. 'It stings more,' said he, and so be began stinging his daughter. I know for a fact there are people who at every blow are worked up to sensuality, to literal sensuality, which increases progressively at every blow they inflict. They beat for a minute, for five minutes, for ten minutes, more often and more savagely. The child screams. At last the child cannot scream, it gasps, 'Daddy daddy!' By some diabolical unseemly chance the case was brought into court. A counsel is engaged. The Russian people have long called a barrister 'a conscience for hire.' The counsel protests in his client's defence. 'It's such a simple thing,' he says, 'an everyday domestic event. A father corrects his child. To our shame be it said, it is brought into court.' The jury, convinced by him, give a favourable verdict. The public roars with delight that the torturer is acquitted. Ah, pity I wasn't there! I would have proposed to raise a subscription in his honour! Charming pictures. But I've still better things about children. I've collected a great, great deal about Russian children, Alyosha. There was a little girl of five who was hated by her father and mother, 'most worthy and respectable people, of good education and breeding.' You see, I must repeat again, it is a peculiar characteristic of many people, this love of torturing children, and children only. To all other types of humanity these torturers behave mildly and benevolently, like cultivated and humane Europeans; but they are very fond of tormenting children, even fond of children themselves in that sense. it's just their defencelessness that tempts the tormentor, just the angelic confidence of the child who has no refuge and no appeal, that sets his vile blood on fire. In every man, of course, a demon lies hidden - the demon of rage, the demon of lustful heat at the screams of the tortured victim, the demon of lawlessness let off the chain, the demon of diseases that follow on vice, gout, kidney disease, and so on."

"This poor child of five was subjected to every possible torture by those cultivated parents. They beat her, thrashed her, kicked her for no reason till her body was one bruise. Then, they went to greater refinements of cruelty - shut her up all night in the cold and frost in a privy, and because she didn't ask to be taken up at night (as though a child of five sleeping its angelic, sound sleep could be trained to wake and ask), they smeared her face and filled her mouth with excrement, and it was her mother, her mother did this. And that mother could sleep, hearing the poor child's groans! Can you understand why a little creature, who can't even understand what's done to her, should beat her little aching heart with her tiny fist in the dark and the cold, and weep her meek unresentful tears to dear, kind God to protect her? Do you understand that, friend and brother, you pious and humble novice? Do you understand why this infamy must be and is permitted? Without it, I am told, man could not have existed 
on earth, for he could not have known good and evil. Why should he know that diabolical good and evil when it costs so much? Why, the whole world of knowledge is not worth that child's prayer to dear, kind God! I say nothing of the sufferings of grown-up people, they have eaten the apple, damn them, and the devil take them all! But these little ones! I am making you suffer, Alyosha, you are not yourself. I'll leave off if you like."

"Nevermind. I want to suffer too," muttered Alyosha.

\section{The Death of an Innocent Child}

"One picture, only one more, because it's so curious, so characteristic, and I have only just read it in some collection of Russian antiquities. I've forgotten the name. I must look it up. It was in the darkest days of serfdom at the beginning of the century, and long live the Liberator of the People! There was in those days a general of aristocratic connections, the owner of great estates, one of those men-somewhat exceptional, I believe, even then-who, retiring from the service into a life of leisure, are convinced that they've earned absolute power over the lives of their subjects. There were such men then. So our general, settled on his property of two thousand souls, lives in pomp, and domineers over his poor neighbours as though they were dependents and buffoons. He has kennels of hundreds of hounds and nearly a hundred dog-boys - all mounted, and in uniform. One day a serf-boy, a little child of eight, threw a stone in play and hurt the paw of the general's favourite hound. 'Why is my favourite dog lame?' He is told that the boy threw a stone that hurt the dog's paw. 'So you did it.' The general looked the child up and down. 'Take him.' He was taken-taken from his mother and kept shut up all night. Early that morning the general comes out on horseback, with the hounds, his dependents, dog-boys, and huntsmen, all mounted around him in full hunting parade. The servants are summoned for their edification, and in front of them all stands the mother of the child. The child is brought from the lock-up. It's a gloomy, cold, foggy, autumn day, a capital day for hunting. The general orders the child to be undressed; the child is stripped naked. He shivers, numb with terror, not daring to cry... 'Make him run,' commands the general. 'Run! run!'shout the dog-boys. The boy runs...'At him!' yells the general, and he sets the whole pack of hounds on the child. The hounds catch him, and tear him to pieces before his mother's eyes!...I believe the general was afterwards declared incapable of administering his estates. Well-what did he deserve? To be shot? To be shot for the satisfaction of our moral feelings? Speak, Alyosha!"

"To be shot," murmured Alyosha, lifting his eyes to Ivan with a pale, twisted smile.

"Bravo!" cried Ivan delighted. "If even you say so... You're a pretty monk! So there is a little devil sitting in your heart, Alyosha Karamazov!"

"What I said was absurd, but..."

"That's just the point, that 'but'!" cried Ivan. "Let me tell you, novice, that the absurd is only too necessary on earth. The world stands on absurdities, and perhaps nothing would have come to pass in it without them. We know what we know!"

"What do you know?"

"I understand nothing," Ivan went on, as though in delirium. "I don't want to understand anything now. I want to stick to the fact. I made up my mind long ago not to understand. If I try to understand anything, I shall be false to the fact, and I have determined to stick to the fact."

"Why are you trying me?" Alyosha cried, with sudden distress. "Will you say what you mean at last?" 
"Of course, I will; that's what I've been leading up to. You are dear to me, I don't want to let you go, and I won't give you up to your Zossima."

Ivan for a minute was silent, his face became all at once very sad.

\section{The Problem of Evil}

"Listen! I took the case of children only to make my case clearer. Of the other tears of humanity with which the earth is soaked from its crust to its centre, I will say nothing. I have narrowed my subject on purpose. I am a bug, and I recognise in all humility that I cannot understand why the world is arranged as it is. Men are themselves to blame, I suppose; they were given paradise, they wanted freedom, and stole fire from heaven, though they knew they would become unhappy, so there is no need to pity them. With my pitiful, earthly, Euclidian understanding, all I know is that there is suffering and that there are none guilty; that cause follows effect, simply and directly; that everything flows and finds its level-but that's only Euclidian nonsense, I know that, and I can't consent to live by it! What comfort is it to me that there are none guilty and that cause follows effect simply and directly, and that I know it?-I must have justice, or I will destroy myself. And not justice in some remote infinite time and space, but here on earth, and that I could see myself. I have believed in it. I want to see it, and if I am dead by then, let me rise again, for if it all happens without me, it will be too unfair. Surely I haven't suffered simply that I, my crimes and my sufferings, may manure the soil of the future harmony for somebody else. I want to see with my own eyes the hind lie down with the lion and the victim rise up and embrace his murderer. I want to be there when everyone suddenly understands what it has all been for. All the religions of the world are built on this longing, and I am a believer. But then there are the children, and what am I to do about them? That's a question I can't answer. For the hundredth time I repeat, there are numbers of questions, but I've only taken the children, because in their case what I mean is so unanswerably clear. Listen! If all must suffer to pay for the eternal harmony, what have children to do with it, tell me, please? It's beyond all comprehension why they should suffer, and why they should pay for the harmony. Why should they, too, furnish material to enrich the soil for the harmony of the future? I understand solidarity in sin among men. I understand solidarity in retribution, too; but there can be no such solidarity with children. And if it is really true that they must share responsibility for all their fathers' crimes, such a truth is not of this world and is beyond my comprehension. Some jester will say, perhaps, that the child would have grown up and have sinned, but you see he didn't grow up, he was torn to pieces by the dogs, at eight years old. Oh, Alyosha, I am not blaspheming! I understand, of course, what an upheaval of the universe it will be when everything in heaven and earth blends in one hymn of praise and everything that lives and has lived cries aloud: 'Thou art just, O Lord, for Thy ways are revealed.'When the mother embraces the fiend who threw her child to the dogs, and all three cry aloud with tears, 'Thou art just, O Lord!' then, of course, the crown of knowledge will be reached and all will be made clear. But what pulls me up here is that I can't accept that harmony. And while I am on earth, I make haste to take my own measures. You see, Alyosha, perhaps it really may happen that if I live to that moment, or rise again to see it, I, too, perhaps, may cry aloud with the rest, looking at the mother embracing the child's torturer, 'Thou art just, O Lord!' but I don't want to cry aloud then. While there is still time, I hasten to protect myself, and so I renounce the higher harmony altogether. It's not worth the tears of that one tortured child who beat itself on the breast with its little fist and prayed in its stinking outhouse, with its unexpiated tears to 'dear, kind God'! It's not worth it, because those tears are unatoned for. They must be atoned for, or there can be no harmony. But how? 
How are you going to atone for them? Is it possible? By their being avenged? But what do I care for avenging them? What do I care for a hell for oppressors? What good can hell do, since those children have already been tortured? And what becomes of harmony, if there is hell? I want to forgive. I want to embrace. I don't want more suffering. And if the sufferings of children go to swell the sum of sufferings which was necessary to pay for truth, then I protest that the truth is not worth such a price. I don't want the mother to embrace the oppressor who threw her son to the dogs! She dare not forgive him! Let her forgive him for herself, if she will, let her forgive the torturer for the immeasurable suffering of her mother's heart. But the sufferings of her tortured child she has no right to forgive; she dare not forgive the torturer, even if the child were to forgive him! And if that is so, if they dare not forgive, what becomes of harmony? Is there in the whole world a being who would have the right to forgive and could forgive? I don't want harmony. From love for humanity I don't want it. I would rather be left with the unavenged suffering. I would rather remain with my unavenged suffering and unsatisfied indignation, even if I were wrong. Besides, too high a price is asked for harmony; it's beyond our means to pay so much to enter on it. And so I hasten to give back my entrance ticket, and if I am an honest man I am bound to give it back as soon as possible. And that I am doing. It's not God that I don't accept, Alyosha, only I most respectfully return him the ticket."

"That's rebellion," murmured Alyosha, looking down.

"Rebellion? I am sorry you call it that," said Ivan earnestly. "One can hardly live in rebellion, and I want to live. Tell me yourself, I challenge your answer. Imagine that you are creating a fabric of human destiny with the object of making men happy in the end, giving them peace and rest at last, but that it was essential and inevitable to torture to death only one tiny creature - that baby beating its breast with its fist, for instance - and to found that edifice on its unavenged tears, would you consent to be the architect on those conditions? Tell me, and tell the truth."

"No, I wouldn't consent," said Alyosha softly 